\title{
IN MEMORIAM: ALONZO CHURCH
}

1903-1995

Alonzo Church's first published paper, Uniqueness of the Lorentz transformation, appeared in the American mathematical monthly in 1924. His most recent paper, $A$ theory of the meaning of names, was published in The heritage of Kazimierz Ajdukiewicz, Rodopi, 1995. This amazing span of seventy-two years embraces a remarkable collection of publications on a wide range of topics in logic and in adjacent parts of philosophy, mathematics, and computer science.

Alonzo Church was born June 14, 1903, in Washington, D.C. Much of his professional life was centered around Princeton University. In 1924 he received his A.B. degree from Princeton. In 1927 he received his Ph.D. there; the title of his dissertation was Alternatives to Zermelo's assumption.

After receiving his doctorate, Church was a National Research Fellow in 1927-29, spending time at Harvard, Göttingen, and Amsterdam. In 1929 he returned to Princeton as an Assistant Professor of Mathematics. He was promoted to Associate Professor in 1939 and to Professor in 1947; from 1961 until leaving Princeton in 1967 he was Professor of Mathematics and Philosophy.

Princeton in the 1930's was an exciting place for logic. There was Church together with his students Rosser and Kleene. There was John von Neumann. Alan Turing, who had been thinking about the notion of effective calculability, came as a visiting graduate student in 1936 and stayed to complete his Ph.D. under Church. And Kurt Gödel visited the Institute for Advanced Study in 1933 and 1935, before moving there permanently.

In 1936 a pair of papers by Church changed the course of logic. An unsolvable problem of elementary number theory, in the American journal of mathematics, formulated what has become known as Church's Thesis: the proposal to identify the "vague intuitive notion" of effective calculability with the precise notion of a recursive function. A note on the Entscheidungsproblem, in the first issue of The journal of symbolic logic, presented what has become known as Church's theorem: the undecidability of validity for first-order logic. His name is also attached to an ordinal number, "Church-Kleene $\omega_{1}$," the least non-recursive ordinal. 
His monograph The calculi of lambda-conversion was published in 1941 by Princeton University Press. The subject of $\lambda$-calculi lately has enjoyed a renaissance, following the discovery of its applicability to theoretical computer science.

In a different direction, Church throughout his career made major contributions to intensional logic, particularly the logic of sense and denotation. And this brief summary only begins to describe the breadth of Church's interests and contributions.

In 1956 Princeton University Press published Church's textbook, Introduction to mathematical logic, Volume I. This was the book that defined the subject for a generation of logicians. There was no Volume II; some of its intended chapters were published as papers.

Church was one of the principal founders of the Association for Symbolic Logic. He guided The journal of symbolic logic from its beginning in 1936, serving as editor for reviews for its first forty-four volumes, and editor for contributed papers for its first fifteen volumes.

Church's work on the reviews was of enormous importance to the field (and of importance to Church personally). There was a time when symbolic logic was viewed with some disapproval both by mathematicians and philosophers. And indeed, many papers of dubious quality appeared. One rôle of the reviews was to allow the logical community itself to say what work was worth while, and to point out shortcomings where they existed.

In 1967 Church decided to retire from Princeton. Upon his retirement, Princeton was unwilling to continue accommodating the small staff working on the reviews for The journal of symbolic logic. Church then moved to UCLA, where he was Kent Professor of Philosophy and Professor of Mathematics. Part of his arrangement with UCLA was that it would support the reviews office as long as Church was its editor.

At UCLA, Church continued active research and publishing, as well as editing the reviews section. And he continued to impress his colleagues with his precision and thoroughness, which showed up in his work, in his use of language, and even in his erasing of a blackboard. As had long been his custom, he would work late at night, when it was quiet and he would not be disturbed. His staff would find notes from him on arrival in the morning. He generally spent summers at his place in the Bahamas.

His wife of fifty years, the former Mary Kuczinski, died in 1976. Church retired from editing the reviews section in 1979. In 1990, Church retired from teaching at UCLA.

In 1992 Church moved from Los Angeles to Hudson, Ohio, where his son, Alonzo Church, Jr., resides. He continued his research, primarily in intensional logic. 
Church died in Hudson on August 11, 1995. Following services at the the University Chapel at Princeton University, he was buried in the Princeton Cemetery. In addition to his son, he is survived by two daughters, Mary Ann Addison and Mildred Dandridge, and by eight grandchildren and two great-grandchildren.

His "academic offspring" are of course his doctoral students. They form a distinguished list indeed:

$\begin{array}{llll}1931 & \text { Alfred L. Foster } & 1959 & \text { Aubert Daigneault } \\ 1934 & \text { Stephen C. Kleene } & 1959 & \text { Raymond Smullyan } \\ 1934 & \text { J. Barkley Rosser } & 1960 & \text { Robert W. Ritchie } \\ 1938 & \text { Alan M. Turing } & 1961 & \text { James R. Guard } \\ 1944 & \text { Enrique Bustamente-Llaca } & 1962 & \text { James Bennett } \\ 1947 & \text { Leon Henkin } & 1962 & \text { Robert O. Winder } \\ 1949 & \text { John G. Kemeny } & 1963 & \text { Wayne H. Richter } \\ 1950 & \text { Martin D. Davis } & 1963 & \text { Gustav B. Hensel } \\ 1951 & \text { Maurice L'Abbé } & 1964 & \text { Peter Andrews } \\ 1952 & \text { William W. Boone } & 1964 & \text { William B. Easton } \\ 1952 & \text { Hartley Rogers, Jr. } & 1965 & \text { Joel W. Robbin } \\ 1955 & \text { Norman Shapiro } & 1967 & \text { Donald J. Collins } \\ 1956 & \text { T. Thacher Robinson } & 1976 & \text { Richard J. (Isaac) Malitz } \\ 1957 & \text { Michael O. Rabin } & 1977 & \text { C. Anthony Anderson } \\ 1958 & \text { Dana Scott } & 1985 & \text { Gary R. Mar } \\ 1959 & \text { Simon Kochen } & & \end{array}$

Church was elected to the National Academy of Sciences in 1978. He was a corresponding member of the British Academy, and a member of the American Academy of Arts and Sciences. He received honorary doctorates from Case Western Reserve (1969), Princeton (1985), and the State University of New York at Buffalo (1990).

An edition of Church's collected papers is planned. It will include a complete bibliography of his publications: not only the books and the research articles, but the numerous reviews (some of which were very influential) and his expository encyclopedia articles.

H. B. ENDERTON 